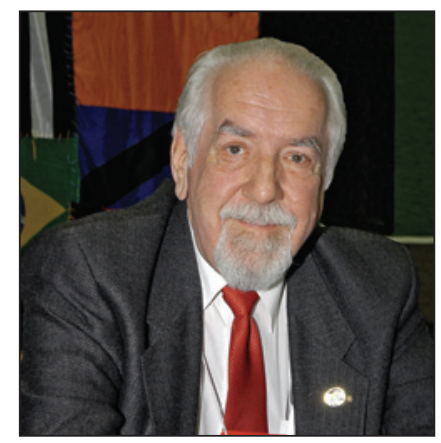

\title{
Em memória do Dr. Alexandre Silveira Tupinambá 14/04/1936 - 14/03/2009
}

Faleceu no último dia 14 de março o oftalmologista Dr. Alexandre Silveira Tupinambá, filho de Da. Elza Silveira Tupinamabá e do Professor Doutor Jacques Tupinambá. Alexandre nasceu em São Paulo, em 14 de abril de 1936. Estudou no tradicional colégio São Luiz, da capital paulista, até o seu ingresso na Escola Paulista de Medicina, no início de 1956, onde colou grau no final de 1962.

Iniciou sua residência médica na Clínica Oftalmológica de Mulheres do Hospital Central da Santa Casa de São Paulo, chefiada por seu pai, Dr. Jacques Tupinambá. Em 1964 casa com a psicóloga Beatriz Motta Pacheco com quem teve três filhos: Alexandre, Luiz Henrique e Adriana e dois netos: Elisa e Matias.

Em 1968 realiza estágio no mundialmente famoso Instituto Barraquer, em Barcelona.

Alexandre pertence a uma ilustre e tradicional família "oftalmológica": seu avô, Dr. Alexandre Tupinambá, foi conceituado oftalmologista baiano, que exerceu a profissão na cidade de Jaú, no interior do estado.

Seu pai, Prof. Dr. Jacques Tupinambá, foi figura de destaque na Oftalmologia Nacional, Diretor do Departamento de Oftalmologia da Santa Casa de São Paulo e Professor de Oftalmologia da Faculdade de Ciências Médicas da Santa Casa. O professor Jacques é o patrono do Centro de Estudos do Departamento de Oftalmologia da Santa Casa de São Paulo.

Alex, como era carinhosamente tratado, teve desde o início de sua carreira profissional a atenção voltada para a pato- logia vitreorretínica, a ela se dedicando com empenho durante toda sua vida. Foi um dos pioneiros, no Brasil, no diagnóstico das "retinopatias" através da angiofluoresceinografia e no uso do laser para o seu tratamento.

Em 1969 funda, com o apoio do Prof. Dr. Arthur Amaral Filho, o curso de especialização em oftalmologia da Santa Casa de São Paulo, ao qual se dedicou intensamente, como professor, nos anos que se seguiram, vendo sua obra florescer e se fortalecer.

Em 1980, realiza estágio, em Boston, com o professor Dr. Schepens, reconhecido universalmente como a autoridade máxima em doenças da retina.

Em seu retorno funda o serviço de oftalmologia do Hospital Beneficência Portuguesa de São Paulo, onde, recebendo todo apoio dos dirigentes da instituição, monta um dos serviços de vitreorretina mais avançados da época o qual Alex manteve atual e atuante por toda a vida.

Alexandre sempre esteve disposto a dividir seus conhecimentos com, os sempre bem recebidos, oftalmologistas mais jovens; era homem de compleição física avantajada, porém, de trato gentil com alunos, pacientes e colegas.

Apreciava a pintura tendo executado coloridas e delicadas aquarelas que ornamentam muitas residências de seus amigos.

A Oftalmologia brasileira perde muito com a ausência de Alexandre Tupinambá.

Estamos tristes com a perda, porém, certos que Alex no momento se dedica a retratar as novas e pacíficas paisagens que o cercam.

Geraldo Vicente de Almeida 